\title{
Lannotinidines H-J, New Lycopodium Alkaloids from Lycopodium annotinum
}

\author{
Kan'ichiro Ishiuchi, ${ }^{a}$ Shihomi Kodama, ${ }^{a}$ Takaaki Kubota,${ }^{a}$ Shigeki Hayashi, ${ }^{b}$ Toshiro Shibata,,${ }^{b}$ and \\ Jun'ichi KoBAYASHI ${ }^{*} a$ \\ ${ }^{a}$ Graduate School of Pharmaceutical Sciences, Hokkaido University; Sapporo 060-0812, Japan: and ${ }^{b}$ Hokkaido Division, \\ Research Center for Medicinal Plant Resources, National Institute of Biomedical Innovation; 108-4 Ohashi, Nayoro, \\ Hokkaido 096-0065, Japan. Received March 12, 2009; accepted May 23, 2009; published online June 3, 2009
}

Three new Lycopodium alkaloids, lannotinidines $\mathrm{H}-\mathrm{J}(1-3)$, were isolated from the club moss Lycopodium annotinum. The structures and relative stereochemistry of $1-3$ were elucidated on the basis of spectroscopic data and the absolute stereochemistry of 2 was assigned by chemical correlation. Lannotinidine $H$ (1) is the first Lycopodium alkaloid possessing a lycopodane skeleton with an additional $\mathrm{C}_{3}$ unit.

Key words Lycopodium alkaloid; Lycopodium annotinum; lannotinidine H; lannotinidine I; lannotinidine J

Club moss (Lycopodiaceae) is known to be a rich source of Lycopodium alkaloids ${ }^{1,2)}$ possessing unique heterocyclic ring systems such as $\mathrm{C}_{16} \mathrm{~N}, \mathrm{C}_{16} \mathrm{~N}_{2}$, and $\mathrm{C}_{27} \mathrm{~N}_{3}$, which have attracted great interest from biogenetic, ${ }^{3,4)}$ synthetic, ${ }^{5,6)}$ and biological ${ }^{7)}$ points of view. Among them, huperzine $\mathrm{A}$ is a highly specific and potent inhibitor of acetylcholine esterase $(\mathrm{AChE}){ }^{7)}$ and the attractive biological profile has promoted the pursuit of the total synthesis and structure activity relationship (SAR) studies of huperzine A. In our continuing efforts to find structurally and biogenetically interesting $L y$ copodium alkaloids, ${ }^{8-10)}$ three new Lycopodium alkaloids, lannotinidines H (1), I (2), and J (3), were isolated from the club moss Lycopodium annotinum together with known alkaloids, lannotinidines A (4) and C (5). ${ }^{11)}$ In this paper, we describe the isolation and structure elucidation of $\mathbf{1}-\mathbf{3}$.

The club moss L. annotinum collected at Nayoro in Hokkaido was extracted with $\mathrm{MeOH}$ aq., and the extracts were partitioned between EtOAc and 3\% tartaric acid. Watersoluble materials, adjusted at $\mathrm{pH} 9$ with sat. $\mathrm{Na}_{2} \mathrm{CO}_{3}$ aq., were partitioned with $\mathrm{CHCl}_{3}$. The $\mathrm{CHCl}_{3}$-soluble materials were subjected to an amino silica gel column ( $n$-hexane/ EtOAc, $1: 0 \rightarrow 1: 1$ and then $\mathrm{CHCl}_{3} / \mathrm{MeOH}, 1: 0 \rightarrow 1: 1$ ), from which a fraction eluted with $\mathrm{CHCl}_{3} / \mathrm{MeOH}(1: 0)$ was further purified with a silica gel column $\left(\mathrm{CHCl}_{3} / \mathrm{MeOH}, 1: 0 \rightarrow 1: 1\right)$ and $\mathrm{a}_{18}$ column $\left(\mathrm{MeCN} / \mathrm{H}_{2} \mathrm{O} /\right.$ trifluoroacetic acid (TFA), $20 / 80 / 0.1 \rightarrow 80 / 20 / 0.1$ ) chromatographies, followed by $\mathrm{C}_{18}$ HPLC $\left(\mathrm{MeCN} / \mathrm{H}_{2} \mathrm{O} / \mathrm{TFA}, 12 / 88 / 0.1\right)$ to afford lannotinidine $\mathrm{H}(\mathbf{1}, 0.57 \mathrm{mg}, 0.00008 \%)$. The fraction eluted from an amino silica gel column with $\mathrm{CHCl}_{3} / \mathrm{MeOH}(10: 1)$ was purified by a silica gel column $\left(\mathrm{CHCl}_{3} / \mathrm{MeOH}, 1: 0 \rightarrow 1: 1\right)$ and then a $\mathrm{C}_{18}$ column $\left(\mathrm{MeCN} / \mathrm{H}_{2} \mathrm{O} / \mathrm{TFA}, 20 / 80 / 0.1 \rightarrow 100 / 0 / 0.1\right)$ chromatographies to get lannotinidine I (2, $14.2 \mathrm{mg}$, $0.002 \%$ ), while a fraction eluted from an amino silica gel
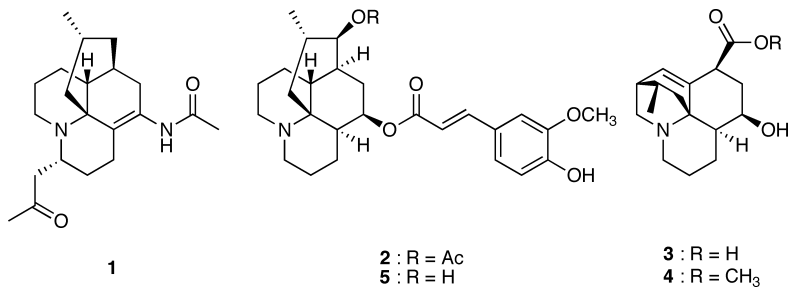

Chart 1 column with $\mathrm{CHCl}_{3} / \mathrm{MeOH}(1: 1)$ was purified by a $\mathrm{C}_{18}$ column $\left(\mathrm{MeCN} / \mathrm{H}_{2} \mathrm{O} / \mathrm{TFA}, 100 / 0 / 0.1 \rightarrow 0 / 100 / 0.1\right)$ and a silica gel column $\left(\mathrm{CHCl}_{3} / \mathrm{MeOH}, 1: 0 \rightarrow 1: 1\right)$ chromatographies, followed by $\mathrm{C}_{18}$ HPLC $\left(\mathrm{MeCN} / \mathrm{H}_{2} \mathrm{O} / \mathrm{TFA}, 5 / 95 / 0.1\right)$ to give lannotinidine $\mathrm{J}(\mathbf{3}, 1.71 \mathrm{mg}, 0.0002 \%)$.

Lannotinidine $\mathrm{H}(\mathbf{1}) \quad\left\{[\alpha]_{\mathrm{D}}^{23}-40.2 \quad(c=0.2, \mathrm{MeOH})\right\}$ showed the pseudomolecular ion peak at $m / z 345(\mathrm{M}+\mathrm{H})^{+}$in the electrospray ionization (ESI)-MS, and the molecular formula, $\mathrm{C}_{21} \mathrm{H}_{32} \mathrm{~N}_{2} \mathrm{O}_{2}$, was established by HR-ESI-MS [ $\mathrm{m} / \mathrm{z}$ 345.2541, $(\mathrm{M}+\mathrm{H})^{+}, \Delta-0.1 \mathrm{mmu}$. IR absorptions implied the presence of secondary amino $\left(3358 \mathrm{~cm}^{-1}\right)$, keto carbonyl $\left(1716 \mathrm{~cm}^{-1}\right)$, and amido carbonyl $\left(1659 \mathrm{~cm}^{-1}\right)$ functionalities. Inspection of ${ }^{1} \mathrm{H}$ - and ${ }^{13} \mathrm{C}-\mathrm{NMR}$ data (Table 1) and the heteronuclear multiple quantum coherence (HMQC) spectrum revealed that $\mathbf{1}$ possessed one keto carbonyl, one amide

Table 1. ${ }^{1} \mathrm{H}$ - and ${ }^{13} \mathrm{C}$-NMR Data of Lannotinidine $\mathrm{H}(\mathbf{1})$ in $\mathrm{CD}_{3} \mathrm{OD}$

\begin{tabular}{clr}
\hline \hline Position & \multicolumn{1}{c}{$\delta_{\mathrm{H}}$} & $\delta_{\mathrm{C}}$ \\
\hline 1 & $4.46(1 \mathrm{H}, \mathrm{m})$ & $53.1 \mathrm{~d}$ \\
2 & $1.78(2 \mathrm{H}, \mathrm{m})$ & $23.9 \mathrm{t}$ \\
$3 \mathrm{a}$ & $2.61(1 \mathrm{H}, \mathrm{m})$ & $22.4 \mathrm{t}$ \\
$3 \mathrm{~b}$ & $2.17(1 \mathrm{H}, \mathrm{m})$ & \\
4 & - & $121.5 \mathrm{~s}$ \\
5 & - & $134.6 \mathrm{~s}$ \\
$6 \mathrm{a}$ & $2.58(1 \mathrm{H}, \mathrm{m})$ & $33.1 \mathrm{t}$ \\
$6 \mathrm{~b}$ & $1.92(1 \mathrm{H}, \mathrm{dd}, 18.6,3.0)$ & \\
7 & $2.06(1 \mathrm{H}, \mathrm{m})$ & $35.1 \mathrm{~d}$ \\
$8 \mathrm{a}$ & $1.72(1 \mathrm{H}, \mathrm{m})$ & $43.0 \mathrm{t}$ \\
$8 \mathrm{~b}$ & $1.33(1 \mathrm{H}, \mathrm{m})$ & \\
9 & $3.28(2 \mathrm{H}, \mathrm{m})$ & $45.1 \mathrm{t}$ \\
$10 \mathrm{a}$ & $1.99(1 \mathrm{H}, \mathrm{brd}, 14.4)$ & $23.6 \mathrm{t}$ \\
$10 \mathrm{~b}$ & $1.84(1 \mathrm{H}, \mathrm{m})$ & \\
$11 \mathrm{a}$ & $1.68(1 \mathrm{H}, \mathrm{dddd}, 12.6,12.6,12.6,3.6)$ & \\
$11 \mathrm{~b}$ & $1.58(1 \mathrm{H}, \mathrm{brd}, 12.6)$ & \\
12 & $1.88(1 \mathrm{H}, \mathrm{m})$ & $44.3 \mathrm{~d}$ \\
13 & - & $69.6 \mathrm{~s}$ \\
$14 \mathrm{a}$ & $2.63(1 \mathrm{H}, \mathrm{m})$ & $41.2 \mathrm{t}$ \\
$14 \mathrm{~b}$ & $1.27(1 \mathrm{H}, \mathrm{m})$ & \\
15 & $1.84(1 \mathrm{H}, \mathrm{m})$ & $28.1 \mathrm{~d}$ \\
16 & $1.00(3 \mathrm{H}, \mathrm{d}, 6.6)$ & $22.0 \mathrm{q}$ \\
17 & $2.94(2 \mathrm{H}, \mathrm{m})$ & $44.9 \mathrm{t}$ \\
18 & - & $206.5 \mathrm{~s}$ \\
19 & $2.21(3 \mathrm{H}, \mathrm{s})$ & $30.2 \mathrm{q}$ \\
20 & $-02(3 \mathrm{H}, \mathrm{s})$ & $22.8 \mathrm{q}$ \\
21 & 2.02 & \\
\hline
\end{tabular}




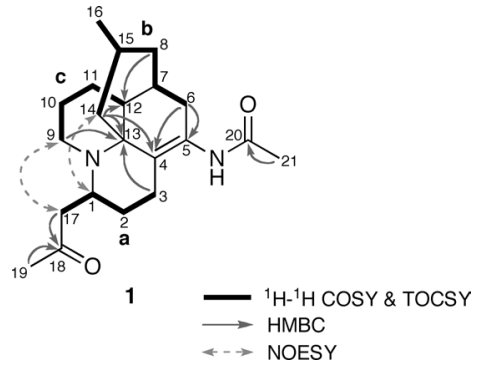

Fig. 1. Selected 2D NMR Correlations for Lannotinidine H (1)

carbonyl, two $s p^{2}$ quaternary carbons, one $s p^{3}$ quaternary carbon, four $s p^{3}$ methines, nine $s p^{3}$ methylenes, and three methyl groups. Among them, one $s p^{3}$ quaternary carbon $\left(\delta_{\mathrm{C}}\right.$ 69.6) and one $s p^{3}$ methine $\left(\delta_{\mathrm{C}} 53.1\right)$ were attributed to carbons bearing a nitrogen atom. The gross structure of 1 was elucidated by analyses of 2 dimentional (2D) NMR data including the ${ }^{1} \mathrm{H}-{ }^{1} \mathrm{H}$ correlation spectroscopy (COSY), total correlation spectroscopy (TOCSY), HMQC, and heteronuclear multiple bond correlation (HMBC) spectra in $\mathrm{CD}_{3} \mathrm{OD}$ (Fig. 1).

The ${ }^{1} \mathrm{H}-{ }^{1} \mathrm{H}$ COSY and TOCSY spectra of 1 revealed three structural units a $(\mathrm{C}-1-\mathrm{C}-3, \mathrm{C}-17), \mathbf{b}(\mathrm{C}-6-\mathrm{C}-8, \mathrm{C}-14-\mathrm{C}-$ $16)$, and $\mathbf{c}(\mathrm{C}-9-\mathrm{C}-12)$. HMBC correlations for $\mathrm{H}-17\left(\delta_{\mathrm{H}}\right.$ $2.94)$ and $\mathrm{H}-19\left(\delta_{\mathrm{H}} 2.21\right)$ to a keto carbonyl carbon $\left(\delta_{\mathrm{C}}\right.$ $206.5)$ revealed that an acetyl group (C-18, C-19) was attached to C-17, while an HMBC cross-peak of H-9 $\left(\delta_{\mathrm{H}} 3.28\right)$ to $\mathrm{C}-13\left(\delta_{\mathrm{C}} 69.6\right)$ suggested that $\mathrm{C}-9\left(\delta_{\mathrm{C}} 45.1\right)$ was connected to $\mathrm{C}-13$ through $\mathrm{N}-9$. The connectivity of C-7 and C12 was elucidated by an HMBC correlation for $\mathrm{H}-8$ a to $\mathrm{C}-12$. HMBC correlations for $\mathrm{H}-14 \mathrm{~b}$ to $\mathrm{C}-4$ and $\mathrm{C}-13, \mathrm{H}-14 \mathrm{a}$ to $\mathrm{C}-$ 12 suggested the connectivities of $\mathrm{C}-4, \mathrm{C}-12$, and $\mathrm{C}-14$ via $\mathrm{C}-13$. An HMBC cross-peak of $\mathrm{H}-3 \mathrm{a}$ to $\mathrm{C}-13$ revealed that C-3 was connected to C-4 $\left(\delta_{\mathrm{C}} 121.5\right)$. The connectivity of C6 to $\mathrm{C}-5\left(\delta_{\mathrm{C}} 134.6\right)$ was suggested by HMBC correlations for $\mathrm{H}-6 \mathrm{~b}$ to $\mathrm{C}-4$ and C-5. An HMBC correlation for $\mathrm{H}-21\left(\delta_{\mathrm{H}}\right.$ $2.02)$ to $\mathrm{C}-20\left(\delta_{\mathrm{C}} 171.6\right)$ revealed that $\mathrm{C}-20$ and $\mathrm{C}-21\left(\delta_{\mathrm{C}}\right.$ 22.8) composed an acetyl group. Nuclear Overhauser enhancement and exchange spectroscopy (NOESY) correlations for $\mathrm{H}-1 / \mathrm{H}-14 \mathrm{a}$ and $\mathrm{H}-\mathrm{-} / \mathrm{H}-17$ suggested that $\mathrm{C}-1$ was connected to N-9. Finally, molecular formula indicated that an acetyl amino group was attached to $\mathrm{C}-5$. Thus, the gross structure of lannotinidine $\mathrm{H}$ was elucidated to be $\mathbf{1}$.

The phase-sensitive NOESY spectrum of $\mathbf{1}$ showed crosspeaks as shown in computer-generated 3D drawing (Fig. 2). The chair form of cyclohexane ring (C-7, C-8, C-12-C-15) and the presence of trans-fused decahydroquinoline ring (C7- $\mathrm{C}-15, \mathrm{~N}-9)$ were deduced from NOESY cross-peaks of $\mathrm{H}-12 / \mathrm{H}-8 \mathrm{~b}$ and $\mathrm{H}-12 / \mathrm{H}-14 \mathrm{~b}$. The methyl group at $\mathrm{C}-15$ was assigned as equatorial from a NOESY correlation for $\mathrm{H}-$ 14b/H-16. A NOESY correlation for $\mathrm{H}-1 / \mathrm{H}-14 \mathrm{a}$ revealed chair form of the piperidine ring $(\mathrm{C}-1-\mathrm{C}-4, \mathrm{C}-13, \mathrm{~N}-9) .{ }^{3} \mathrm{~J}$ value $(12.6 \mathrm{~Hz})$ between $\mathrm{H}-11 \mathrm{a}$ and $\mathrm{H}-12$, and a NOESY correlation for $\mathrm{H}-6 \mathrm{a} / \mathrm{H}-11 \mathrm{a}$ suggested that the piperidine ring (C-9- C-13, N-9) was chair form and the cyclohexene ring (C-4-C-7, C-12, C-13) was half-chair form. The $\alpha$-orientation of $\mathrm{C}_{3}$ unit $(\mathrm{C}-17-\mathrm{C}-19)$ at $\mathrm{C}-1$ was revealed by a NOESY correlation for $\mathrm{H}-9 / \mathrm{H}-17$. Thus, the relative stereostructure of lannotinidine H (1) was elucidated to be shown in Fig. 2.

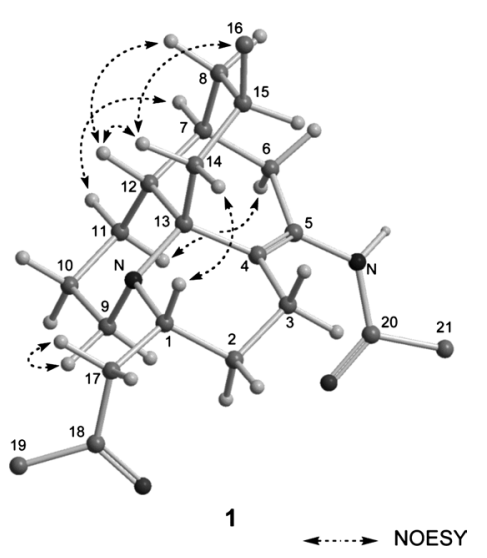

Fig. 2. Selected NOESY Correlations and Relative Stereochemistry for Lannotinidine $\mathrm{H}$ (1)

Hydrogen atoms of methyl groups were omitted.

Table 2. ${ }^{1} \mathrm{H}$ - and ${ }^{13} \mathrm{C}-\mathrm{NMR}$ Data of Lannotinidine I (2) in $\mathrm{CDCl}_{3}$

\begin{tabular}{|c|c|c|}
\hline Position & $\delta_{\mathrm{H}}$ & $\delta_{\mathrm{C}}$ \\
\hline $1 \mathrm{a}$ & $3.62(1 \mathrm{H}, \mathrm{m})$ & $47.0 \mathrm{t}$ \\
\hline $1 b$ & $3.09(1 \mathrm{H}, \mathrm{m})$ & \\
\hline $2 \mathrm{a}$ & $1.93(1 \mathrm{H}, \mathrm{m})$ & $18.7 \mathrm{t}$ \\
\hline $2 \mathrm{~b}$ & $1.85(1 \mathrm{H}, \mathrm{m})$ & \\
\hline $3 a$ & $1.85(1 \mathrm{H}, \mathrm{m})$ & $20.7 \mathrm{t}$ \\
\hline $3 b$ & $1.61(1 \mathrm{H}, \mathrm{m})$ & \\
\hline 4 & $2.63(1 \mathrm{H}, \mathrm{m})$ & $32.5 \mathrm{~d}$ \\
\hline 5 & $5.34(1 \mathrm{H}, \mathrm{dd}, 6.9,6.9)$ & $67.1 \mathrm{~d}$ \\
\hline 6 & $1.97(2 \mathrm{H}, \mathrm{m})$ & $24.2 \mathrm{t}$ \\
\hline 7 & $2.23(1 \mathrm{H}, \mathrm{m})$ & $37.0 \mathrm{~d}$ \\
\hline 8 & $4.65(1 \mathrm{H}, \mathrm{dd}, 10.9,5.2)$ & $78.4 \mathrm{~d}$ \\
\hline $9 \mathrm{a}$ & $3.42(1 \mathrm{H}, \mathrm{m})$ & $46.6 \mathrm{t}$ \\
\hline $9 b$ & $3.32(1 \mathrm{H}, \mathrm{m})$ & \\
\hline $10 \mathrm{a}$ & $2.16(1 \mathrm{H}, \mathrm{m})$ & $22.6 \mathrm{t}$ \\
\hline $10 \mathrm{~b}$ & $1.92(1 \mathrm{H}, \mathrm{m})$ & \\
\hline $11 \mathrm{a}$ & $1.73(1 \mathrm{H}, \mathrm{m})$ & $22.0 \mathrm{t}$ \\
\hline $11 \mathrm{~b}$ & $1.55(1 \mathrm{H}, \mathrm{m})$ & \\
\hline 12 & $2.16(1 \mathrm{H}, \mathrm{m})$ & $40.7 \mathrm{~d}$ \\
\hline 13 & - & $61.4 \mathrm{~s}$ \\
\hline $14 \mathrm{a}$ & $2.63(1 \mathrm{H}, \mathrm{m})$ & $36.9 \mathrm{t}$ \\
\hline $14 \mathrm{~b}$ & $1.81(1 \mathrm{H}, \mathrm{m})$ & \\
\hline 15 & $2.95(1 \mathrm{H}, \mathrm{m})$ & $28.9 \mathrm{~d}$ \\
\hline 16 & $1.07(3 \mathrm{H}, \mathrm{d}, 6.3)$ & $19.7 \mathrm{q}$ \\
\hline 17 & - & $166.2 \mathrm{~s}$ \\
\hline 18 & $6.20(1 \mathrm{H}, \mathrm{d}, 16.1)$ & $114.6 \mathrm{~d}$ \\
\hline 19 & $7.59(1 \mathrm{H}, \mathrm{d}, 16.1)$ & $145.9 \mathrm{~d}$ \\
\hline 20 & - & $126.4 \mathrm{~s}$ \\
\hline 21 & $7.01(\mathrm{~d}, 1.7)$ & $109.6 \mathrm{~d}$ \\
\hline 22 & - & $146.9 \mathrm{~s}$ \\
\hline 23 & - & $148.5 \mathrm{~s}$ \\
\hline 24 & $6.95(\mathrm{~d}, 8.1)$ & $115.0 \mathrm{~d}$ \\
\hline 25 & $7.09(\mathrm{dd}, 8.1,1.8)$ & $123.1 \mathrm{~d}$ \\
\hline 26 & $3.92(3 \mathrm{H}, \mathrm{s})$ & $56.0 \mathrm{q}$ \\
\hline 27 & - & $170.5 \mathrm{~s}$ \\
\hline 28 & $2.01(3 \mathrm{H}, \mathrm{s})$ & $21.1 \mathrm{q}$ \\
\hline
\end{tabular}

Lannotinidine I (2) $\left\{\left[\alpha_{\mathrm{D}}^{22}+24.4(c=0.4, \mathrm{MeOH})\right\}\right.$ showed the pseudomolecular ion peak at $m / z 484(\mathrm{M}+\mathrm{H})^{+}$in the FAB-MS, and the molecular formula, $\mathrm{C}_{28} \mathrm{H}_{37} \mathrm{NO}_{6}$, was established by HR-FAB-MS $\left[\mathrm{m} / \mathrm{z} 484.2693,(\mathrm{M}+\mathrm{H})^{+}, \Delta\right.$ $-0.7 \mathrm{mmu}$. The IR spectrum suggested the presence of hydroxy $\left(3383 \mathrm{~cm}^{-1}\right)$, and carbonyl $\left(1731,1682 \mathrm{~cm}^{-1}\right)$ functionalities. ${ }^{1} \mathrm{H}$ - and ${ }^{13} \mathrm{C}-\mathrm{NMR}$ data (Table 2 ) and the HMQC spectrum suggested that the structure of 2 was similar to lannotinidine $\mathrm{C}(\mathbf{4}){ }^{11)}$ The gross structure of 2 was elucidated 


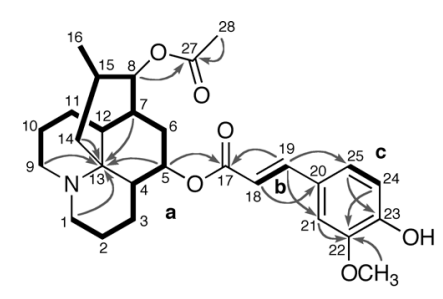

2

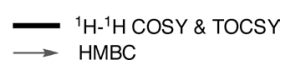

Fig. 3. Selected 2D NMR Correlations for Lannotinidine I (2)

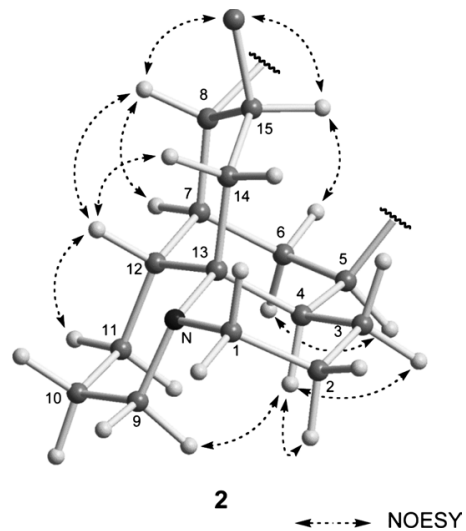

Fig. 4. Selected NOESY Correlations and Relative Stereochemistry for Lannotinidine I (2)

Hydrogen atoms of a methyl group and acyl groups were omitted.

by analyses of 2D NMR data including the ${ }^{1} \mathrm{H}-{ }^{1} \mathrm{H}$ COSY, TOCSY, HMQC, and HMBC spectra in $\mathrm{CDCl}_{3}$ (Fig. 3).

The ${ }^{1} \mathrm{H}-{ }^{1} \mathrm{H}$ COSY and TOCSY spectra of 2 revealed three structural units a $(\mathrm{C}-1-\mathrm{C} 8, \mathrm{C}-9-\mathrm{C}-12, \mathrm{C}-14-\mathrm{C}-16)$, b $(\mathrm{C}-$ 18, C-19), and $\mathbf{c}(\mathrm{C}-24, \mathrm{C}-25)$. HMBC correlations of $\mathrm{H}-1 \mathrm{~b}$ $\left(\delta_{\mathrm{H}} 3.09\right)$ and $\mathrm{H}-9 \mathrm{~b}\left(\delta_{\mathrm{H}} 3.32\right)$ to $\mathrm{C}-13\left(\delta_{\mathrm{C}} 61.4\right)$ revealed that C-1 $\left(\delta_{\mathrm{C}} 47.0\right), \mathrm{C}-9\left(\delta_{\mathrm{C}} 46.6\right)$, and C-13 were connected through a nitrogen atom. The connectivities of $\mathrm{C}-4, \mathrm{C}-12$, and $\mathrm{C}-14$ via $\mathrm{C}-13$ were elucidated by $\mathrm{HMBC}$ correlations for $\mathrm{H}-5, \mathrm{H}-7$, and $\mathrm{H}-14$ to $\mathrm{C}-13$. HMBC correlations for $\mathrm{H}-8$ $\left(\delta_{\mathrm{H}} 4.65\right)$ and $\mathrm{H}-28$ to $\mathrm{C}-27\left(\delta_{\mathrm{C}} 170.5\right)$ revealed that an acetoxy group was connected to $\mathrm{C}-8\left(\delta_{\mathrm{C}} 78.4\right)$. The presence of an E-3-methoxy-4-hydroxy cinnamoyl group was disclosed by HMBC cross-peaks depicted in Fig. 3 and a large coupling constant $(16.1 \mathrm{~Hz})$ for $\mathrm{H}-18$ and H-19. Positions of an $E$-3-methoxy-4-hydroxy cinnamoyl group was assigned by an HMBC correlation for H-5 to C-17. Thus, the gross structure of lannotinidine I was elucidated to be $\mathbf{2}$.

The relative stereochemistry of $\mathbf{2}$ was deduced as follows. ${ }^{3} \mathrm{~J}$ value $(10.9 \mathrm{~Hz})$ between H-8 and H-15 and NOESY correlations for $\mathrm{H}-8 / \mathrm{H}-12, \mathrm{H}-4 / \mathrm{H}-5$ and $\mathrm{H}-4 / \mathrm{H}-9 \mathrm{a}$ suggested the relative stereochemistry of $\mathrm{C}-4, \mathrm{C}-5, \mathrm{C}-7, \mathrm{C}-8, \mathrm{C}-12$, and $\mathrm{C}$ 15 to be as shown in Fig. 4. The $\beta$-orientation of an $E$-3methoxy-4-hydroxy cinnamoyl group at C-5 was supported by ${ }^{3} J$ values between $\mathrm{H}-4$ and $\mathrm{H}-5$, and $\mathrm{H}-5$ and $\mathrm{H}-6$ (both $6.9 \mathrm{~Hz})$.

The absolute stereochemistry of $\mathbf{2}$ was elucidated by chemical correlation with lannotinidine C (5), ${ }^{11)}$ whose absolute stereochemistry has been established. Acetylation of $\mathbf{5}$ with acetic anhydride in pyridine gave a diacetyl derivative, whose aryl acetate was selectively deprotected using silica
Table 3. ${ }^{1} \mathrm{H}$ - and ${ }^{13} \mathrm{C}-\mathrm{NMR}$ Data of Lannotinidine $\mathrm{J}(3)$ in $\mathrm{CD}_{3} \mathrm{OD}$

\begin{tabular}{|c|c|c|}
\hline Position & $\delta_{\mathrm{H}}$ & $\delta_{\mathrm{C}}$ \\
\hline 1 & $3.41(2 \mathrm{H}, \mathrm{m})$ & $49.6 \mathrm{t}$ \\
\hline 2 & $2.03(2 \mathrm{H}, \mathrm{m})$ & $24.5 \mathrm{t}$ \\
\hline $3 a$ & $1.89(1 \mathrm{H}, \mathrm{m})$ & $20.2 \mathrm{t}$ \\
\hline $3 b$ & $1.63(1 \mathrm{H}, \mathrm{m})$ & \\
\hline 4 & $2.04(1 \mathrm{H}, \mathrm{m})$ & $42.0 \mathrm{~d}$ \\
\hline 5 & $4.21(1 \mathrm{H}, \mathrm{m})$ & $66.5 \mathrm{~d}$ \\
\hline $6 a$ & $2.54(1 \mathrm{H}, \mathrm{m})$ & $34.6 \mathrm{t}$ \\
\hline $6 \mathrm{~b}$ & $1.29(1 \mathrm{H}, \mathrm{ddd}, 14.1,14.1,7.2)$ & \\
\hline 7 & $3.42(1 \mathrm{H}, \mathrm{m})$ & $41.9 \mathrm{~d}$ \\
\hline 8 & - & $175.0 \mathrm{~s}$ \\
\hline $9 \mathrm{a}$ & $3.15(1 \mathrm{H}, \mathrm{d}, 12.0)$ & $49.0 \mathrm{t}$ \\
\hline $9 b$ & $3.00(1 \mathrm{H}, \mathrm{d}, 12.0)$ & \\
\hline 10 & $2.55(1 \mathrm{H}, \mathrm{m})$ & $35.6 \mathrm{~d}$ \\
\hline 11 & $6.54(1 \mathrm{H}, \mathrm{dd}, 6.9,2.4)$ & $130.4 \mathrm{~d}$ \\
\hline 12 & & $141.4 \mathrm{~s}$ \\
\hline 13 & & $62.7 \mathrm{~s}$ \\
\hline $14 \mathrm{a}$ & $2.05(1 \mathrm{H}, \mathrm{m})$ & $28.3 \mathrm{t}$ \\
\hline $14 \mathrm{~b}$ & $1.92(1 \mathrm{H}, \mathrm{m})$ & \\
\hline 15 & $1.76(1 \mathrm{H}, \mathrm{m})$ & $30.2 \mathrm{~d}$ \\
\hline 16 & $1.19(3 \mathrm{H}, \mathrm{d}, 6.6)$ & $17.3 \mathrm{q}$ \\
\hline & $\begin{array}{l}\longrightarrow{ }^{1} \mathrm{H}^{-1} \mathrm{H} \operatorname{COSY} \& \text { TOCSY } \\
\longrightarrow \mathrm{HMBC}\end{array}$ & \\
\hline
\end{tabular}

Fig. 5. Selected 2D NMR Correlations for Lannotinidine J (3)

gel supported ammonium formate under micro wave irradiation $^{12)}$ to obtaine 2 . The spectral data and the $[\alpha]_{\mathrm{D}}$ value $\left\{[\alpha]_{\mathrm{D}}^{22}+27.4(c=0.4, \mathrm{MeOH})\right\}$ of derived 2 were coincident with those of natural 2 . Thus, the absolute configurations at seven chiral centers of lannotinidine I (2) were assigned as $4 S, 5 R, 7 S, 8 R, 12 R, 13 R$, and $15 S$.

Lannotinidine J (3) $\left\{[\alpha]_{\mathrm{D}}^{23}+17.8 \quad(c=0.7, \mathrm{MeOH})\right\}$ showed the pseudomolecular ion peak at $m / z 278(\mathrm{M}+\mathrm{H})^{+}$in the FAB-MS, and the molecular formula, $\mathrm{C}_{16} \mathrm{H}_{23} \mathrm{NO}_{3}$, was established by HR-FAB-MS $\left[\mathrm{m} / \mathrm{z} 278.1745,(\mathrm{M}+\mathrm{H})^{+}, \Delta\right.$ $+1.1 \mathrm{mmu}$. IR absorptions implied the presence of hydroxy $\left(3384 \mathrm{~cm}^{-1}\right)$ and carbonyl $\left(1682 \mathrm{~cm}^{-1}\right)$ functionalities. ${ }^{1} \mathrm{H}$ and ${ }^{13} \mathrm{C}-\mathrm{NMR}$ data (Table 3 ) and the HMQC spectrum revealed the presence of 16 carbons due to one carbonyl carbon, one $s p^{2}$ quaternary carbon, one $s p^{3}$ quaternary carbon, one $s p^{2}$ methine, five $s p^{3}$ methines, six $s p^{3}$ methylenes, and one methyl group, in which one $s p^{3}$ methine $\left(\delta_{\mathrm{C}} 66.5\right)$ was attributed to a carbon connected to a hydroxy group. The gross structure of $\mathbf{3}$ was elucidated by analyses of 2D NMR data including the ${ }^{1} \mathrm{H}-{ }^{1} \mathrm{H}$ COSY, TOCSY, HMQC, and HMBC spectra in $\mathrm{CD}_{3} \mathrm{OD}$ (Fig. 5).

The ${ }^{1} \mathrm{H}-{ }^{1} \mathrm{H}$ COSY and TOCSY spectra of 3 revealed two structural units a $(\mathrm{C}-1-\mathrm{C}-7)$ and b $(\mathrm{C}-9-\mathrm{C}-11, \mathrm{C}-14-\mathrm{C}-$ 16). HMBC correlations of $\mathrm{H}-9 \mathrm{~b}\left(\delta_{\mathrm{H}} 3.00\right)$ to $\mathrm{C}-1\left(\delta_{\mathrm{C}} 49.6\right)$ and H-1 $\left(\delta_{\mathrm{H}} 3.41\right)$ to $\mathrm{C}-13\left(\delta_{\mathrm{C}} 62.7\right)$ revealed that C-1, C-9 $\left(\delta_{\mathrm{C}} 49.0\right)$, and $\mathrm{C}-13$ were connected through a nitrogen atom. The presence of carboxylic acid at $\mathrm{C}-7$ was suggested by HMBC cross-peaks of $\mathrm{H}-6 \mathrm{~b}$ and $\mathrm{H}-7$ to $\mathrm{C}-8\left(\delta_{\mathrm{C}} 175.0\right)$. The 


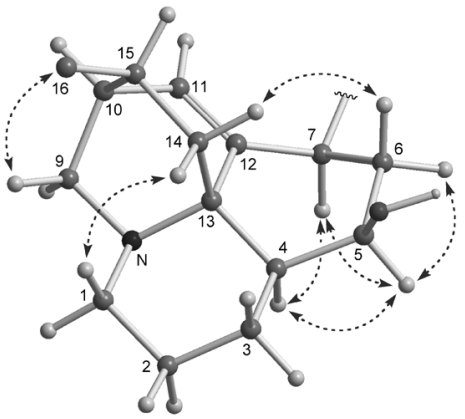

3

$+\cdots \rightarrow$ NOESY

Fig. 6. Selected NOESY Correlations and Relative Stereochemistry for Lannotinidine $\mathrm{J}(\mathbf{3})$

Hydrogen atoms of a methyl group and a carboxy group were omitted.

connectivity of C-7 $\left(\delta_{\mathrm{C}} 41.9\right)$ and C-11 $\left(\delta_{\mathrm{C}} 130.4\right)$ through $\mathrm{C}-12\left(\delta_{\mathrm{C}} 141.4\right)$ was revealed by HMBC correlations for $\mathrm{H}-$ $6 \mathrm{~b}$ and $\mathrm{H}-10$ to $\mathrm{C}-12$. HMBC correlations for $\mathrm{H}-5$ and $\mathrm{H}-14 \mathrm{~b}$ to $\mathrm{C}-13$, and $\mathrm{H}-14 \mathrm{~b}$ to $\mathrm{C}-12$ revealed that $\mathrm{C}-4, \mathrm{C}-12$, and $\mathrm{C}-$ 14 were connected via $\mathrm{C}-13$. Thus, the gross structure of lannotinidine $\mathrm{J}$ was elucidated to be $\mathbf{3}$.

The relative stereochemistry of $\mathbf{3}$ was deduced from NOESY correlations as shown in computer-generated 3D drawing (Fig. 6). The $\alpha$-configurations of $\mathrm{H}-4, \mathrm{H}-5$, and $\mathrm{H}-7$ were revealed by NOESY correlations among $\mathrm{H}-4, \mathrm{H}-5$, and $\mathrm{H}-7$, and twist-boat form of cyclohexene ring (C-4 - C-7, C$12, \mathrm{C}-13$ ) was suggested by a NOESY correlation for $\mathrm{H}-4 / \mathrm{H}-$ 7. NOESY correlations for H-1/H-14b, H-5/H-6a, and H$6 \mathrm{~b} / \mathrm{H}-14 \mathrm{a}$ supported the relative stereochemistry of $\mathrm{C}-13$ and chair-form of a piperidine ring $(\mathrm{C}-1-\mathrm{C}-4, \mathrm{C}-13, \mathrm{~N})$. The relative stereochemistry of $\mathrm{C}-15$ was deduced by a NOESY cross-peak of $\mathrm{H}-9 \mathrm{~b} / \mathrm{H}-16$. Thus, the structure of lannotinidine $\mathrm{J}$ was elucidated to be $\mathbf{3}$, corresponding to free acid form of lannotinidine A (4). ${ }^{11)}$

Lannotinidine $\mathrm{H}(\mathbf{1})$ is the first Lycopodium alkaloid possessing a lycopodane skeleton with an additional $\mathrm{C}_{3}$ unit. Lannotinidines $\mathrm{H}-\mathbf{J}(\mathbf{1}-\mathbf{3})$ did not show cytotoxicities against P388 and L1210 murine leukemia, and KB human epidermoid carcinoma cells $\left(\mathrm{IC}_{50}>10.0 \mu \mathrm{g} / \mathrm{ml}\right)$ in vitro.

\section{Experimental}

General Methods Optical rotation was recorded on a JASCO P-1030 polarimeter. IR and UV spectra were recorded on JASCO FT/IR-230 and Shimadzu UV-1600PC spectrophotometer, respectively. ${ }^{1} \mathrm{H}-,{ }^{13} \mathrm{C}-$, and $2 \mathrm{D}-$ NMR spectra were recorded on a Bruker AMX-600 and a JEOL ECA-500 spectrometers. Each NMR sample of lannotinidines H (1) and J (3) was prepared by dissolving in $50 \mu 1$ of $\mathrm{CD}_{3} \mathrm{OD}$ in $2.5 \mathrm{~mm}$ micro cells (Shigemi Co., Ltd.) and chemical shifts were reported using residual $\mathrm{CD}_{3} \mathrm{OD}\left(\delta_{\mathrm{H}} 3.31\right.$ and $\left.\delta_{\mathrm{C}} 49.0\right)$ as internal standard, while that of lannotinidine I (2) was prepared by dissolving in $500 \mu 1$ of $\mathrm{CDCl}_{3}$ in $5.0 \mathrm{~mm}$ micro cells (Shigemi Co., Ltd.) and chemical shifts reported using residual $\mathrm{CDCl}_{3}\left(\delta_{\mathrm{H}} 7.26\right.$ and $\left.\delta_{\mathrm{C}} 77.0\right)$ as internal standard. Standard pulse sequences were employed for the 2D-NMR experiments. ${ }^{1} \mathrm{H}-{ }^{1} \mathrm{H}$ COSY, TOCSY, and NOESY spectra were measured with spectral widths of both dimensions of $4800 \mathrm{~Hz}$, and 32 scans with two dummy scans were accumulated into $1 \mathrm{~K}$ data points for each of $256 t_{1}$ increments. NOESY and TOCSY spectra in the phase-sensitive mode were measured with a mixing time of 800 and $30 \mathrm{~ms}$, respectively. For HMQC spectra in the phase-sensitive mode and HMBC spectra, a total of 256 increments of $1 \mathrm{~K}$ data points were collected. For HMBC spetra in the phase-sensitive mode and HMBC spectra, a total of 256 increments of $1 \mathrm{~K}$ data points were collected. For HMBC spectra with $Z$-axis PFG, 20 and $50 \mathrm{~ms}$ delay time were used for long-range $\mathrm{C}-\mathrm{H}$ coupling. Zero-filling to $1 \mathrm{~K}$ for $F_{1}$ and multiplication with squared cosine-bell windows shifted in both dimensions were performed prior to 2D Fourier transformation. ESI mass spectra were obtained on a JEOL JMS-700TZ spectrometer. FAB mass spectra were obtained on a JEOL JMS-HX110 spectrometer.

Plant Material The club moss Lycopodium annotinum was collected in Nayoro, Hokkaido in Japan, in 2007. The botanical identification was made by Dr. T. Shibata, Hokkaido Division, Research Center for Medicinal Plant Resources, National Institute of Biomedical Innovation. A voucher specimen has been deposited in the herbarium of Hokkaido University.

Extraction and Separation The club moss L. annotinum collected at Nayoro in Hokkaido was extracted with $\mathrm{MeOH}$ aq., and extracts were partitioned between EtOAc and 3\% tartaric acid $(\mathrm{pH} 4)$. Water-soluble materials, adjusted at $\mathrm{pH} 9$ with sat. $\mathrm{Na}_{2} \mathrm{CO}_{3}$ aq., were partitinoned with $\mathrm{CHCl}_{3}$. $\mathrm{CHCl}_{3}$-soluble materials were subjected to an amino silica gel column (nhexane/EtOAc, $1: 0 \rightarrow 1: 1$ and then $\left.\mathrm{CHCl}_{3} / \mathrm{MeOH}, 1: 0 \rightarrow 1: 1\right)$. A fraction eluted with $\mathrm{CHCl}_{3} / \mathrm{MeOH}(1: 1)$ was further purified by a silica gel column $\left(\mathrm{CHCl}_{3} / \mathrm{MeOH}, 1: 0 \rightarrow 1: 1\right)$ and then a $\mathrm{C}_{18}$ column $\left(\mathrm{MeCN} / \mathrm{H}_{2} \mathrm{O} / \mathrm{TFA}\right.$, $20 / 80 / 0.1 \rightarrow 80 / 20 / 0.1)$ chromatographies. A fraction eluted with $\mathrm{MeCN} /$ $\mathrm{H}_{2} \mathrm{O} /$ TFA $(20 / 80 / 0.1)$ was further purified by $\mathrm{C}_{18}$ HPLC $\left(\mathrm{MeCN} / \mathrm{H}_{2} \mathrm{O} / \mathrm{TFA}\right.$, $12 / 88 / 0.1)$ to afford lannotinidine $\mathrm{H}(\mathbf{1}, 0.57 \mathrm{mg}, 0.00008 \%)$. A fraction eluted from an amino silica gel column with $\mathrm{CHCl}_{3} / \mathrm{MeOH}(10: 1)$ was purified by a silica gel column $\left(\mathrm{CHCl}_{3} / \mathrm{MeOH}, 1: 0 \rightarrow 1: 1\right)$ and then a $\mathrm{C}_{18}$ column $\left(\mathrm{MeCN} / \mathrm{H}_{2} \mathrm{O} / \mathrm{TFA}, 20 / 80 / 0.1 \rightarrow 100 / 0 / 0.1\right)$ chromatographies. A fraction eluted with $\mathrm{MeCN} / \mathrm{H}_{2} \mathrm{O} / \mathrm{TFA}(40 / 60 / 0.1)$ afforded lannotinidine I (2, $14.2 \mathrm{mg}, 0.002 \%)$. Finally, a fraction eluted from an amino silica gel column with $\mathrm{CHCl}_{3} / \mathrm{MeOH}(1: 1)$ was purified by a $\mathrm{C}_{18}$ column $\left(\mathrm{MeCN} / \mathrm{H}_{2} \mathrm{O} / \mathrm{TFA}\right.$, $100 / 0 / 0.1 \rightarrow 0 / 100 / 0.1)$ chromatography, from which a fraction eluted with $\left(\mathrm{MeCN} / \mathrm{H}_{2} \mathrm{O} / \mathrm{TFA}, 20 / 80 / 0.1\right)$ was purified with a silica gel column $\left(\mathrm{CHCl}_{3} /\right.$ $\mathrm{MeOH}, 1: 0 \rightarrow 1: 1)$ chromatography and then $\mathrm{C}_{18}$ HPLC $\left(\mathrm{MeCN} / \mathrm{H}_{2} \mathrm{O} / \mathrm{TFA}\right.$, $5 / 95 / 0.1)$ to afford lannotinidine $\mathrm{J}(\mathbf{3}, 1.71 \mathrm{mg}, 0.0002 \%)$.

Lannotinidine $\mathrm{H}(\mathbf{1})$ : Colorless amorphous solids; $[\alpha]_{\mathrm{D}}^{23}-40.2(c=0.2$, $\mathrm{MeOH})$; IR (film) $v_{\max } 3358,2921,2850,1716$, and $1659 \mathrm{~cm}^{-1} ;{ }^{1} \mathrm{H}-$ and ${ }^{13} \mathrm{C}$-NMR see Table 1; ESI-MS $\mathrm{m} / \mathrm{z} 345(\mathrm{M}+\mathrm{H})^{+}$; HR-ESI-MS $\mathrm{m} / \mathrm{z}$ $345.2541\left(\mathrm{M}+\mathrm{H}\right.$; Calcd for $\left.\mathrm{C}_{21} \mathrm{H}_{33} \mathrm{~N}_{2} \mathrm{O}_{2}, 345.2542\right)$.

Lannotinidine I (2): Colorless amorphous solids; $[\alpha]_{\mathrm{D}}^{22}+24.4(c=0.4$, $\mathrm{MeOH}) ; \mathrm{UV}(\mathrm{MeOH}) \lambda_{\max } 328(\varepsilon 12500), 236(7800)$, and $218(9600) \mathrm{nm}$; IR (film) $v_{\max } 3384,2958,1731$, and $1682 \mathrm{~cm}^{-1} ;{ }^{1} \mathrm{H}-$ and ${ }^{13} \mathrm{C}-\mathrm{NMR}$ see Table 2; FAB-MS $m / z 484(\mathrm{M}+\mathrm{H})^{+}$; HR-FAB-MS $m / z 484.2693(\mathrm{M}+\mathrm{H}$; Calcd for $\mathrm{C}_{28} \mathrm{H}_{38} \mathrm{NO}_{6}, 484.2700$ ).

Lannotinidine J (3): Colorless amorphous solids; $[\alpha]_{D}^{23}+17.8(c=0.7$, $\mathrm{MeOH}$ ); IR (film) $v_{\max } 3384,2922,2850$, and $1682 \mathrm{~cm}^{-1}$; ${ }^{1} \mathrm{H}$ - and ${ }^{13} \mathrm{C}-\mathrm{NMR}$ see Table 3; ESI-MS $m / z 278(\mathrm{M}+\mathrm{H})^{+}$; HR-ESI-MS $m / z 278.1745(\mathrm{M}+\mathrm{H}$; Calcd for $\mathrm{C}_{16} \mathrm{H}_{24} \mathrm{NO}_{3}, 278.1734$ ).

Chemical Correlation of Lannotinidine C (5) ${ }^{11)}$ to Lannotinidine I (2) Lannotinidine $\mathrm{C}(\mathbf{5}, 10.0 \mathrm{mg})$ was treated with $\mathrm{Ac}_{2} \mathrm{O}(500 \mu \mathrm{l})$ and pyridine $(500 \mu \mathrm{l})$ at room temperature for $22 \mathrm{~h}$, then the mixture was concentrated in vacuo to afford diacetyl derivative of lannotinidine C (5) (8.2 mg). Diacetyl derivative of $5(1.9 \mathrm{mg})$ was mixed with ammonium formate $(2.4 \mathrm{mg})$ and silica gel $(50 \mathrm{mg})$ in a glass tube, which was placed at the center of an almina bath. After irradiation of micro wave for $4 \mathrm{~min}$, the glass tube was cooled to room temperature. The reaction mixture was extracted with EtOAc, and the extract was concentrated in vacuo and purified by a $\mathrm{C}_{18}$ HPLC [CAPCELL PAK AQ, Shiseido Co., Ltd., $10 \times 250 \mathrm{~mm}$; eluent, $\mathrm{CH}_{3} \mathrm{CN} / \mathrm{H}_{2} \mathrm{O} / \mathrm{TFA}, 12: 88: 0.1$; flow rate, $2.0 \mathrm{ml} / \mathrm{min}$; UV detection at $210 \mathrm{~nm}]$ to afford a reaction product $(1.8 \mathrm{mg})$, whose spectral data and the $[\alpha]_{\mathrm{D}}$ value $\left\{[\alpha]_{\mathrm{D}}^{22}+27.4(c=0.4, \mathrm{MeOH})\right\}$ were coincident with those of natural 2

Acknowledgments The authors thank Ms. S. Oka and Ms. A. Tokumitsu, Center for Instrumental Analysis, Hokkaido University, for measurements of ESI and FAB-MS, respectively. This work was partly supported by a research fellowship for young scientists from the Japan Society for the Promotion of Science (to K. I.), and a Grant-in-Aid for Scientific Research from the Ministry of Education, Culture, Sports, Science and Technology of Japan.

\section{References and Notes}

1) Hirasawa Y., Kobayashi J., Morita H., Heterocycles, 77, 679-729 (2009).

2) Kobayashi J., Morita H., "The Alkaloids," Vol. 61, ed. by Cordell G. A., Academic Press, New York, 2005, pp. 1-57.

3) Hemscheidt T., Spenser I. D., J. Am. Chem. Soc., 118, 1799-1800 (1996).

4) Hemscheidt T., Spenser I. D., J. Am. Chem. Soc., 115, 3020-3021 (1993). 
5) Douglas B. C., Amos S. B., J. Am. Chem. Soc., 130, 13778-13789 (2008).

6) Staben S. T., Kennedy-Smith J. J., Huang D., Corkey B. K., LaLonde R. L., Toste F. D., Angew. Chem. Int. Ed., 45, 5991-5994 (2006).

7) Liu J. S., Zhu Y. L., Yu C. M., Zhou Y. Z., Han Y. Y., Wu F. W., Qi B. F., Can. J. Chem., 64, 837-839 (1986).

8) Ishiuchi K., Kubota T., Morita H., Kobayashi J., Tetrahedron Lett., 47, 3287-3289 (2006).
9) Ishiuchi K., Kubota T., Mikami Y., Obara Y., Nakahata N., Kobayashi J., Bioorg. Med. Chem., 15, 413-417 (2007).

10) Kubota T., Yahata H., Ishiuchi K., Obara Y., Nakahata N., Kobayashi J., Heterocycles, 74, 843-848 (2007).

11) Koyama K., Morita H., Hirasawa Y., Yoshinaga M., Hoshino T., Obara Y., Nakahata N., Kobayashi J., Tetrahedron, 61, 3681-3690 (2005).

12) Ramesh C., Mahender G., Ravindranath N., Das B., Green Chem., 5, $68-70(2003)$. 